 \\ Сравнительный анализ топонимов в русском и китайском языках
} в аспекте лексико-семантических особенностей номинации

\author{
Ши Цзялу
}

\begin{abstract}
Аннотация. Цель исследования - выявление лексико-семантических особенностей номинации топонимических единиц в русском и китайском языках в сравнительном аспекте. В статье рассматривается общая специфика топонимов; исследуются лексико-семантические особенности номинации топонимов в указанных языках. Научная новизна состоит в том, что в работе впервые проведено комплексное исследование русских и китайских топонимов в аспекте лексико-семантических особенностей номинации. В результате доказано, что топонимы в китайском языке носят образный, метафоричный характер, отражая эстетическое восприятие нации, тогда как русскоязычные топонимы связаны с конкретными фактами, личностями, реалиями.
\end{abstract}

\section{Lexico-Semantic Features of Toponymic Nomination in the Russian and Chinese Languages (Comparative Analysis)}

Shi Jialu

\begin{abstract}
The paper aims to identify lexico-semantic features of toponymic nomination in the Russian and Chinese languages in a comparative aspect. The author analyses distinctive features of toponyms, examines lexico-semantic features of the Russian and Chinese toponymic nominations. Scientific originality of the study lies in the fact that the researcher for the first time provides a comprehensive lexico-semantic analysis of the Russian and Chinese toponymic units. As a result, it is proved that the Chinese toponyms are figurative and metaphorical, they represent the Chinese people's aesthetic worldview, whereas the Russian toponyms are associated with concrete facts, persons, reality.
\end{abstract}

\section{Введение}

Актуальность темы исследования обусловлена целым рядом факторов: во-первых, необходимостью рассмотрения проблемы языковых особенностей китайской топонимии, которая (проблема), в свою очередь, раскрывает важные вопросы, связанные с:

- $\quad$ функционированием данного класса лексики в современном информационном пространстве, в т.ч. в туристической сфере;

- трансляцией ценностных характеристик в межкультурной и межъязыковой коммуникации;

- формированием и передачей концептов, выявляющихся не только на лексическом, но и лингвоэстетическом уровнях в диалоге лингвокультур, что, безусловно, имеет большое значение для развития современной лингвистической науки.

Во-вторых, актуальность определяется важностью сопоставительного анализа топонимов в рамках типологически различающихся языков с целью выявления лексико-семантических особенностей номинации топонимических единиц в русском и китайском языках в сравнительном аспекте, в т.ч. в контексте междисциплинарных направлений обучения. Топонимы как пласт лексики, заключающий в себе культурно-историческую информацию, являются важным фрагментом «языковой картины мира, аккумулирующей этнический опыт и национальные особенности в зависимости от языка» [7, с. 325]. Сравнительный анализ способствует выявлению специфики номинации и особенностей языковой картины мира носителей русского и китайского языков, что является актуальным для России и Китая как стран, осуществляющих активный межкультурный контакт.

Для достижения цели следует решить ряд задач: во-первых, рассмотреть общую специфику русских и китайских топонимов; во-вторых, исследовать лексико-семантические особенности номинации топонимов в русском и китайском языках. Для выявления общей специфики русских и китайских топонимов, а также их 
лексико-семантических особенностей номинации в данной работе используются следующие методы исследования: общенаучные методы (анализ, синтез, сравнение, аналогия), методы оценки, интерпретации и классификации фактического материала. Материалом исследования служат топонимические единицы, описанные и систематизированные в рамках топонимических словарей и научно-исследовательских изданий, составленных Я. А. Миропольским [1], Е. М. Поспеловым [6], Хуа Линьфу [9] и др.

Теоретической базой исследования послужили работы современных авторов, исследующих топонимику Китая, специфику китайских топонимов (А. С. Космачева и Ш. Шао [2], А. С. Кравченко [3], Чжан Чжуаннянь и Ван Линсу [10] и др.); осуществляющих сравнительный анализ русских и китайских топонимов, в т.ч. в контексте описания способов и мотивов наименования китайских и русскоязычных топонимов (Л. Лю [4], С. Н. Сокольникова [7] и др.); а также раскрывающих проблематику изучения топонимов через описание компонентов языковой картины мира (Г. Т. Омарова [5], Ф. Г. Фаткуллина [8] и др.).

Практическая значимость исследования заключается в том, что материалы настоящей статьи могут использоваться в педагогической практике, в т.ч. в преподавании русского языка как иностранного, преподавании китайского языка в русскоязычной аудитории, переводоведения, языкознания. Также возможно создание специального пособия, содержащего в себе топонимический материал русского и китайского языков: пособие может быть использовано в преподавании лингвострановедения, изучении топонимики Китая и России, культурологии.

\section{Общая специфика русских и китайских топонимов}

Топонимы (греч. topos - место, местность + опіта - имя) представляют собой лексику, обозначающую названия географических объектов. Топонимика (наука, изучающая топонимы) рассматривает географические названия, их значение и структуру, этимологию, ареал распространения топонимов, а также трансформацию топонима со временем [5]. Как лингвокультурологический концепт топонимы выражают национальный колорит места, к которому они принадлежат, являясь своеобразным культурным кодом, содержащим в себе «социокультурный и ментальный опыт народа», нашедший отражение в языке (в частности, в формировании топонима) [4, с. 99]. Когнитивная лингвистика рассматривает топонимы как результат процесса мышления: национально-культурные знания, проходя через сознание носителя языка, кодируются в виде топонима, формируя языковую картину мира народа. Мировосприятие происходит как через рационально-логическое мышление, так и осмыслением и оценкой мира через созерцание, прочувствование, что заключается в топониме и придает ему особый культурно-философский смысл [8]. Топонимы также являются и географическим концептом, имея пространственную привязку и служа средством обозначения местонахождения.

Образование топонимов в китайском языке обусловлено историческими и геополитическими мотивами. Долгое время Китай был закрытым от внешнего мира государством, что способствовало формированию своеобразной, уникальной культуры, не подвергшейся влиянию извне. Топоним в китайском языке представляет собой лексику, созданную с помощью корнесложения и представленную в графическом виде иероглифами, являющимися способом фиксации картины мира [3, с. 376]. Наиболее распространенные модели словообразования топонимов - это:

- прилагательное + существительное («южные горы» / Наньщань);

- существительное + существительное («спокойствие»+ «здоровье»=Анькан);

- числительное + существительное («три реки» / Саньшуй).

Для русского языка более характерно суффиксальное словообразование: -ов (Львов), -ев- (Князево), -ин(Марьино), -ск (Томск, Климовск). В китайском языке топонимы в связи с тем, что обозначались иероглифами, почти не изменяющими свою форму, сохранили изначальную семантику, поэтому китайские топонимы являются неизменными на протяжении многих лет. В русском языке топонимы на письме обозначаются прописной буквой в начале, а также в некоторых случаях используется дефис. Топоним в китайском языке образуется в соответствии с правилами словообразования в китайском языке (начальный компонент определяет последующий). Структура топонимов в китайском языке состоит из собственно названия и идентификатора класса географического объекта, который помещается в конце топонима, что не распространено в русском языке.

Распространенными формантами китайской топонимии являются -ань (берег), -ту (земля, почва), фу (гора, холм), -лин (лес), -шань (гора), -лу (дорога), -гоу (канава, ров), -ся (ущелье), -тунь (поселение), -мэнь (дверь, дорога), -мяо (монастырь, храм), -дао (остров), -тань (мель, остров), -дин (вершина), -фэн (вершина), -ган (холм), -бэй (север), -вань (залив), -хай (море), -хэ (река), -цзян (большая река, гавань), -юань, цюань (источник, ручей), -чи (озеро), -юньхэ (канал), -нань (юг) и т.д. [6]. Наличие таких формантов позволяет получить первичную информацию о географическом объекте, а также определить вид топонима (наиболее распространенные: ойконимы (названия населенных пунктов), гидронимы (названия водных объектов: реки, озера, моря и т.д.), оронимы (названия гор, особенностей рельефа местности) и т.д.).

Таким образом, в проблематику настоящего исследования входит переводоведческий аспект, так как при переводе, а также в коммуникации необходимо достичь адекватности в процессе передачи информации с одного языка на другой, чего не всегда удается достичь при переводе имен собственных, а также топонимов, что актуально при переводе художественной литературы (в контексте межличностной коммуникации топонимы передаются с помощью транскрипции и калькирования). Знание топонимов способствует 
не только углублению знаний о родном языке и его культуре, но также содействует погружению в культуру изучаемого иностранного языка (в частности, китайского).

\section{Лексико-семантические особенности номинации топонимов в русском и китайском языках}

Семантика топонимов носит на себе отпечаток различных условий в зависимости от географического объекта [4]. Анализ лексико-семантических особенностей номинации топонимов в русском и китайском языках позволил выделить следующие типы топонимических единиц.

1. Топонимы, номинации которых связаны с природой и окружающей средой. В значительной степени в смысловой структуре топонимов отражаются условия жизни народа, характеристики географического объекта и т.д. Так, в России имеется множество гор на Востоке, однако на Западе преобладают равнины. В свою очередь, в Китае Запад является горным местом, Восток - равнинным. Отсюда такие топонимы, как Пятигорск, Солнечногорск; Мааньшань (马鞍山). На семантику топонимов влияют и водные объекты: Томск (на реке Томь), Волгоград (на Волге); Саньшуй (三水 - «три реки»).

2. Топонимы, связанные с минеральными ресурсами. Россия является страной с большим количеством месторождений, запасов нефти, угля и других природных ресурсов, их добыча часто способствует образованию вокруг месторождений поселений, образующих города, а также отражается на названии места: Нефтеюганск, Нефтекамск, Магнитогорск, Соликамск. В Китае также существует множество промышленных городов, основанных на месторождениях минеральных ресурсов: Байинь (白银 - серебро), Тунлин (铜陵 - медные горы) [1].

3. Топонимы, соотносимые с названиями растений. Преобладание определенного вида растений может послужить наименованию данного места топонимом, содержащим в своей структуре название данного растения: Липецк (липа), Черемхово (черемуха); Таоюань (桃园 - персиковый сад), Люлинь (柳林 - ивовый лес). Некоторые названия мест в Китае получили свое название по сходству с определенным растением (город Лянь назван по форме горного хребта, напоминающего цветок лотоса - 莲).

4. Топонимы, связанные с названиями животных. В России данный вид топонима обусловлен преобладанием отдельных животных на определенной местности или же мифологией: Бобруйск (словом «бобр» обозначали людей, занимающихся рыболовством и ловлей бобров в обозначаемой местности [6]), Mышкин, Орел, Pыбинск, Оленегорск, Змеиногорск. В Китае большинство названий, соотносимых с животными, навязаны сходством топографии местности и определенного животного: Баоцзи (宝鸡 - драгоценная курица; назван по форме горного хребта, имеющего сходство с курицей [9]), Фэйлун (飞龙 - Летающий дракон; по форме города на карте).

5. Топонимы, номинации которых связаны с экономикой и хозяйством. На название определенных мест значительно повлияли экономическое развитие и осуществляемая на территории хозяйственная деятельность: Ловцы (жители деревни занимаются рыбалкой), Торжок (от слова «торг»); Ян Чжуан (羊庄 - село овечье), Юй Ши (鱼市 - рыбный рынок).

6. Топонимы, имеющие в названии антропонимы. Имена деятелей культуры также находят свое отражение в национальных топонимах: Пушкин (по имени А. С. Пушкина), Чехов (по имени А. П. Чехова), Екатеринбург (назван в честь Екатерины I), Хабаровск (в честь землепроходца Ерофея Хабарова), Ярославль (в честь Ярослава Мудрого). В Китае такие топонимы делятся на два вида: топонимы, в названии которых заложены имена первых людей, живущих на обозначаемой территории (Шицзячжуан / 石家庄 - деревня семьи Ши), и топонимы, названные по самой часто встречающейся фамилии в местности (Тяньчжуан / 田庄- деревня семьи Тянь).

7. Топонимы, связанные с религией и символикой. И Китай, и Россия имеют собственные религиозные понятия, отражающиеся в топонимах. В России они раскрывают христианские понятия: Дмитриевск (от имени святого Дмитрия); Воскресенск (от праздника «Воскресение Христово»), Рождествено (от праздника «Рождество Христово»), Борисоглебск (в честь святых великомучеников Бориса и Глеба). В Китае, в свою очередь, есть свои религиозные традиции, реалии: Вэньчан, Вэньсин (соотносится с божеством, приносящим удачу в карьере и в делах), Сянью (仙游县 - уезд, в котором путешествуют боги).

8. Топонимы, определяющие военную деятельность. В России и Китае существует множество топонимов, соотносящихся с войной, так как обе страны имеют в своей истории периоды долгих войн не только в национальном, но и в мировом масштабе. Многие города в России являются городами воинской славы, а также имеют звание «город-герой». Военная деятельность часто отражается в годонимах (переулок 1905 года, улица 1812 года, Кутузовский проспект) [1]. В Китае некоторые места названы по победам, одержанным в войнах: Хоцзя (获嘉县 - получить хорошие новости в уезде). Великая Китайская стена, величайший архитектурный памятник Китая, когда-то была оборонительным сооружением [7]. Однако в русском языке данная семантика представлена в структуре топонима не так широко, как в китайском языке.

Кроме того, в китайском языке при помощи топонимии определяются стороны света (иероглифы, обозначающие сторону света, входят в состав топонима). Различается пять направлений: восток (东/дун), запад (西/си), юг (南/нань), север (北/бэй), центр/центральный/средний (中/чжун). Например: Наньчан, Нанкин, Пекин (Бэйцзин), Шаньдун, Чжунго (Китай) [2]. Влияние оказала также концепция «инь» (阴) и «ян» (阳): Лоян, Ханьинь, Ханьян. Китайские топонимы, в отличие от русскоязычных, характеризуются высокой степенью метафоричности (Фуцзянь - «место, где живет счастье», Тяньцзинь - «место, где видно небо» (данное место специально обустраивалось, чтобы гости смогли посмотреть на китайского императора - Сына Неба) и др.). 


\section{Заключение}

Таким образом, мы приходим к следующим выводам. Топонимы в китайском языке носят образный, метафоричный характер, отражая эстетическое восприятие нации, тогда как русскоязычные топонимы связаны с отражением конкретных фактов, личностей и т.д. Топонимы являются лексикой, сохраняющей в своей семантике знания о языке и культуре страны, о национальной истории, об этническом опыте и мировосприятии народа. Особенно это характерно для китайского языка, топонимы которого состоят из иероглифов, практически не изменяющихся по структуре. Топонимия в русском и китайском языке имеет общие лексикосемантические особенности называния, однако наблюдаются и отличия.

Как в русском, так и в китайском языке топонимы носят на себе отпечаток окружающей среды обозначаемого места (по рельефу, водному объекту и т.д.). Различные природные ресурсы также отражаются в названии топонимов (растения, минеральные ресурсы), особенно это сказывается на промышленных городах, образованных на местах обнаружения месторождений. Наименования по растениям в Китае имеют некоторую особенность, так как некоторые места названы не только по преобладанию определенного растения в местности, но также и по сходству с формой растения, ввиду чего для образования топонима используется образный метод. Названия, соотносимые с антропонимами, в Китае также имеют лексико-семантическую особенность, если в России топоним назван чаще всего по имени одного какого-либо деятеля, то в Китае топонимы в своей структуре содержат коллективный антропоним (самая распространенная фамилия на территории или же фамилии первых людей, живших в данной местности) и т.д.

Перспективы дальнейшего исследования проблемы видятся в более детальном рассмотрении лексикосемантических особенностей номинации топонимов в русском и китайском языках с целью адаптации под использование в качестве материала в рамках различных дисциплин, а также в исследовании различных видов и типов топонимов в русском и китайском языках.

\section{Источники | References}

1. Инструкция по русской передаче географических названий Китая / сост. Я. А. Миропольский; ред. Г. Е. Тихонова. М.: Наука, 1983. 132 с.

2. Космачева А. С., Шао Ш. Особенности топонимов в китайском языке // Язык и культура: сб. ст. XXVI Междунар. науч. конф. Томск: НИТГУ, 2016. С. 204-206.

3. Кравченко А. С. Особенности формирования топонимики Китая // Современные научные исследования и разработки. 2018. № 11 (28). С. 375-377.

4. Лю Л. Способы и мотивы наименования географических объектов в китайском и русском языках // Litera. 2021. № 5. С. 97-105.

5. Омарова Г. Т. Теоретические проблемы изучения топонимов: онтологический и гносеологический аспекты [Электронный ресурс]. URL: http://www.rusnauka.com/4_SND_2012/Philologia/3_99890.doc.htm (дата обращения: 13.05.2021).

6. Поспелов Е. М. Географические названия мира: топонимический словарь / отв. ред. Р. А. Агеева. Изд-е 2-е, стер. М.: Русские словари, 2002. 512 с.

7. Сокольникова С. Н. Сопоставительное исследование топонимов русского и китайского языков // Мир науки, культуры, образования. 2011. № 6 (31). Ч. 1. С. 324-326.

8. Фаткуллина Ф. Г. Топонимическая лексика как отражение национальной языковой картины мира // European Social Science Journal (Европейский журнал социальных наук). 2014. № 3. Т. 1. С. 212-225.

9. 华林甫. 中国地名学源流. 人民出版社: 2010年. 444页 (Хуа Линьфу. Происхождение топонимии в Китае. Пекин: Народ. изд-во, 2010. 444 с.).

10. 张壮年. 王林绪主编. 中国地名的故事. 山东画报出版社: 2006年. 280页 (Чжан Чжуаннянь, Ван Линсу. История китайских топонимов. Пекин: Изд-во Шаньдун, 2006. 280 с.).

\section{Информация об авторах | Author information}

RU Ши Цзялу 1

${ }^{1}$ Российский университет дружбы народов, г. Москва

EN Shi Jialu ${ }^{1}$

${ }^{1}$ Peoples' Friendship University of Russia, Moscow

1964226971@qq.com

\section{Информация о статье | About this article}

Дата поступления рукописи (received): 19.05.2021; опубликовано (published): 30.06.2021.

Ключевые слова (keywords): топонимические единицы; лексико-семантические особенности номинации; русский язык; китайский язык; сравнительный анализ; toponymic units; lexico-semantic features of nomination; Russian language; Chinese language; comparative analysis. 